\title{
THE MACMILLAN COMPANION TO SCOTTISH LITERATURE
}




\section{THE MACMILLAN COMPANION \\ TO SCOTTISH LITERATURE}

TREVOR ROYLE

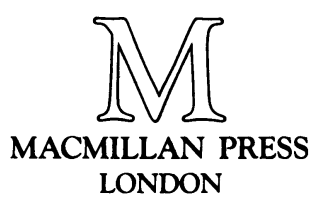


All rights reserved. No part of this publication may be reproduced or transmitted, in any form or by any means, without permission.

First published 1983 by

THE MACMILLAN PRESS LTD

London and Basingstoke

Associated Companies throughout the world

First published in paperback 1984

British Library Cataloguing in Publication Data

Royle, Trevor

The Macmillan companion to Scottish literature.

1. English literature - Scottish authors - History and criticism -

Dictionaries

2. Scottish literature - History and criticism - Dictionaries

3. Gaelic literature - History and criticism-Dictionaries

I. Title

820.9'9411'0321 PR8506

ISBN 978-0-333-37871-7

ISBN 978-1-349-07587-4 (eBook)

DOI 10.1007/978-1-349-07587-4

ISBN 978-0-333-37871-7 Pbk

The paperback edition of this book is sold subject to the condition that it shall not, by way of trade or otherwise, be lent, resold, hired out, or otherwise circulated without the publisher's prior consent in any form of binding or cover other than that in which it is published and without a similar condition including this condition being imposed on the subsequent purchaser

Filmsetting by Vantage Photosetting Co. Ltd., Eastleigh and London 


\section{Contents}

ACKNOWLEDGEMENTS

page

INTRODUCTION

vii

BIBLIOGRAPHICAL INFORMATION

ABBREVIATIONS

xi

THE DICTIONARY 


\section{Acknowledgements}

First and foremost I wish to thank the general editor of this Companion and its 'onlie begetter', Professor A. N. Jeffares of the University of Stirling, both for his useful advice and helpful criticism and for his unfailing support throughout the project. I owe debts of gratitude, too, to the following friends who have helped on several matters through conversations or correspondence: Dr Ian Campbell, University of Edinburgh; Douglas Gifford, University of Strathclyde; Professor Francis Russell Hart, University of Massachusetts; and Dr Roderick Watson, University of Stirling. I was also greatly assisted by the many writers and publishers who replied to my requests for biographical or bibliographical information; and I was fortunate in having such a tolerant publisher. It would be invidious of me not to acknowledge the courtesies and encouragement afforded to me by Shaie Selzer and Mara Vilcinskas of Macmillan and I should like to thank Rosemary Roberts for editing the copy. Professor William Gillies, of the University of Edinburgh, kindly read the sections relating to Gaelic literature and suggested improvements and alterations. Walter Perrie assisted with the correction of proofs and helped in many other untold ways; to him go my thanks, although all errors in the text must remain my responsibility. No book of this kind could have been attempted without the excellent services of the National Library of Scotland and throughout I have been both assisted and heartened by the helpful ministrations of its staff. Likewise, the staffs of the Scottish and the Edinburgh Rooms of the Edinburgh Central Library, and of the Mitchell Library in Glasgow, offered their customary friendly help and advice. 


\section{Introduction}

The purpose of this Companion is to provide an alphabetical list of references to Scotland's literature from earliest times to the present day. Its backbone is supplied by the biographical essays devoted to the principal poets, novelists, dramatists, critics and men of letters who have written in English, Scots or Gaelic and whose work constitutes the main corpus of Scottish literature. Also included are a number of historians, philosophers, divines, diarists and other occasional writers who may be considered to have made their own contribution through the literary worth of their writings. Where writers have pseudonyms these are listed but the reader is referred back in each case to the writer's real name. Working outwards from the biographical essays through a system of cross-referencing there are further essays which cover the following fields: principal literary works, institutions, literary movements, historical events and personalities, printed ephemera and publishing.

The length of an essay must of course to some extent be determined by its subject's worth, but the reader should not use bulk as a guide in every case. Some writers led fuller, better-documented lives and published more books than others: of necessity their entries are longer than those on equally important writers, the facts of whose lives may be more obscure. In each entry I have tried to provide the date and place of birth and death and the principal facts of the writer's life. Most writers were born and brought up in Scotland or could claim Scottish nationality through parentage, but I have not allowed myself to be over-dominated by the claims of nationhood. Several writers spent most of their working lives outside the country of their birth and never returned. Others who stayed were not always completely under the influence of Scotland, its culture and its traditions. A handful of writers of nationalities other than Scottish spent their lives in Scotland and through their writings added to the heritage of their adopted land. I have chosen to include all three types. In the space available it has not been possible to provide original literary criticisms, although by way of aesthetic comment I have attempted to give a critical viewpoint of the writer or the work under discussion.

The impingement of history on the nation's literature could not be ignored. Thus cognisance is taken of the kings and queens, the statesmen and the main events that have influenced in some way the world of letters. Similarly the religions of Scotland and the writings inspired by their espousal find a place, as does the law, which has played such an influential role in shaping Scotland's intellectual traditions. There are also essays devoted to the Scottish philosophers, particularly to those associated with the Scottish Common-Sense school.

Gaelic created a different problem. Although it is now a minority language, its literature, especially its poetry and its song tradition, has made a signal contribution to Scotland's literature. Not being a Gaelic speaker I am denied access to many of the texts, other than to those published with English translations. As a consequence, the references to Gaelic writers and to Gaelic literature may appear to be restricted but the diligent reader will discover that many of the main writers are included. Following the example of Professor Derick Thomson in his Introduction to Gaelic Poetry (London, 1974), the Gaelic writers have been listed under their Gaelic names. Duncan Ban MacIntyre appears under 'Mac an t-Saoir, Donnchadh Bàn'; but where the writer has used Gaelic and English in equal measure, he is entered under the English form of his name ('Iain Crichton Smith' is preferred to 'Iain Mac a'Ghobhainn').

During the preparation of the Companion, the standard of choice and selection was always under review and several writers on the fringe were omitted because it was felt that their work had been too marginal. With contemporary writers, no one has been included who was born after 1950 and in most cases caution has been preferred to commitment in offering a literary judgement. The process of any 


\section{viii Introduction}

literature is bound to be continuous and those writers will one day find themselves subjected to different standards of selection and compilation in future companions to Scottish literature.

Finally, this Companion will have served something of its purpose if it can act as a companionable guide and introduction to Scotland's own very distinctive voice as reflected in its national literature.

\section{Trevor Royle}

Edinburgh, August 1982 


\section{Bibliographical Information}

The biographical essays are based in the main, though not exclusively, on entries in the Dictionary of National Biography and on Who's Who for the relevant years. The other main works consulted were: D. Irving, The Lives of the Scottish Poets (Edinburgh, 1804); R. Chambers, A Biographical Dictionary of Eminent Scotsmen, 4 vols. (Edinburgh, 1832-4); W. Anderson, The Scottish Nation, 9 vols. (Edinburgh and London, 1882); Scottish Biographies 1938 (London, 1938); and G. Donaldson and R. S. Morpeth, eds., Who's Who in Scottish History (Oxford, 1973). Wherever possible, reference has been made to the publications of the Scottish Text Society, the Association for Scottish Literary Studies and the Scottish Gaelic Text Society. These provide admirable critical introductions to the principal texts of Scotland's literature.

At the conclusion of each writer's biographical essay are listed his or her book publications, but in some cases complete or collected editions of works, have been preferred to a listing of individual titles. Plays are dated according to their first production but when published, the date of publication has been given in the 'Works' section. The main critical and biographical studies have also been listed (in the 'References' section) but lack of space prevented reference to individual critical essays in literary magazines and journals.

The following books provided the main body of critical study and should be consulted in addition to those individual studies referred to in the text.

Aitken, A. J. and McArthur, T., The Languages of Scotland (Edinburgh, 1979)

Bold, A., The Ballad (London, 1979)

Buchan, D., The Ballad and the Folk (London, 1972)

Campbell, I., ed., Nineteenth Century Scottish Fiction (Manchester, 1979)

Collinson, F., The Traditional and National Music of Scotland (London, 1966)

Craig, D., Scottish Literature and the Scottish People (London, 1961)

Daiches, D., The Paradox of Scottish Culture (Oxford, 1964)

Daiches, D., ed., A Companion to Scottish Culture (London, 1981)

Davie, G., The Democratic Intellect (Edinburgh, 1961)

Fulton, R., Contemporary Scottish Poetry: Individuals and Contexts (Loanhead, Midlothian, 1974)

Glen, D., A Bibliography of Scottish Poets from Stevenson to 1974 (Preston, 1974)

Grierson, H. J. C., ed., Edinburgh Essays on Scots Literature (Edinburgh and London, 1933)

Hart, F. R., The Scottish Novel: a Critical Survey (London, 1978)

Henderson, T. F., Scottish Vernacular Literature: a History (London, 1900)

Jack, R. D. S., The Italian Influence on Scottish Literature (Edinburgh, 1970)

Kinsley, J., ed., Scottish Poetry: a Critical Survey (London, 1955)

Lindsay, M., The Burns Encyclopaedia (London, 1959; rev. 1980)

$\longrightarrow$, History of Scottish Literature (London, 1977)

Mackenzie, A. M., An Historical Survey of Scottish Literature to 1714 (London, 1933)

Maclean, M., The Literature of the Highlands (London, 1925)

McNeill, F. M., The Silver Bough, 4 vols. (Glasgow, 1957-68)

MacQueen, J. and Scott, T., eds., The Oxford Book of Scottish Verse (Oxford, 1965)

Millar, J. H., A Literary History of Scotland (Edinburgh and London, 1903)

Muir, E., Scott and Scotland (London, 1936)

Shire, H. M., Song, Dance and Poetry of the Court of Scotland under King James VI (Cambridge, 1969)

Smith, G. G., Scottish Literature: Character and Influence (London, 1919) 


\section{x Bibliographical Information}

Smith, J. M., The French Background of Middle Scots Literature (London, 1934)

Speirs, J., The Scots Literary Tradition (London, 1962)

Thomson, D., An Introduction to Gaelic Poetry (London, 1974)

Wittig, K., The Scottish Tradition in Literature (Edinburgh, 1958) 


\section{Abbreviations}

ASLS Association for Scottish Literary Studies

$D N B$ Dictionary of National Biography

$O E D$ Oxford English Dictionary

SGTS Scottish Gaelic Text Society

SND Scottish National Dictionary

STS Scottish Text Society 